\title{
Public Debt and Financial Crises in the Twentieth
} Century

Moritz Schularick

School of Business \& Economics

Discussion Paper

Economics

2012/1 


\title{
Public Debt and Financial Crises in the Twentieth Century
}

\author{
Moritz Schularick \\ Department of Economics, John.-F.-Kennedy-Institute, Free University of Berlin, Berlin, \\ Germany
}

(January 2012)

\begin{abstract}
The costs of wars have been the main driver of public debt in the Western World during the modern era. The late twentieth century stands out as a period that saw a pronounced increase of government debt to GDP ratios in peacetime. This paper assesses the role that financial crises have played in shaping the public debt trajectory in the twentieth century. Focusing on the experiences of 14 industrial economies, I show that financial crises have long and lasting effects on public finances. I provide evidence that the costs of financial crises have increased strongly in the second half of the twentieth century and that the costs of financial crises grow with the size of the financial sector. In many countries, the rising costs incurred from stabilizing the economy after financial crises were an important cause of the peacetime surge of public debt ratios in the late twentieth century. In today's highly financialized economies, financial crises have become a key risk for public finances.
\end{abstract}

*moritz.schularick@fu-berlin.de

Katharina Gärtner provided excellent research assistance as did Christian Lüdde and Felix Mihram who helped with data collection. This work was supported by a grant of the National Academy of Sciences in the context of the interdisciplinary "Working Group on Public Debt" of which the author is a member. I wish to thank, without implicating, Carl-Ludwig Holtfrerich, Irwin Collier, Niall Ferguson, and Alan Taylor for many helpful discussions of this topic. Part of this research was undertaken while the author was a Visiting Professor at the Economics Department of New York University, Stern School of Business. The support of NYU-Stern is gratefully acknowledged. 
At the time of this paper's writing, the global financial crisis that began with the collapse of the US housing market in 2007 had morphed into a serious political and economic crisis in Europe threatening the survival of the common European currency. It is difficult to imagine a clearer illustration of the severe political consequences that financial crises can have. The 2008 crisis emanated from a private sector credit boom and housing bubble in the USA, but turned into a sovereign debt crisis in Europe when bail-outs and ballooning budget deficits led to a sharp increase of public debt levels. Financial markets started to question the sustainability of public debt levels in countries that were affected most strongly from the fallout of the previous (private sector) credit boom (Ireland and Spain) as well as those countries where the sustainability of already high levels of public debt to GDP became questionable when the economic outlook deteriorated (Italy, Portugal, Greece). When markets started to worry about debt sustainability, interest rates rose sharply and public debt dynamics deteriorated further.

The past four years clearly illustrate that crises can take a large toll on public sector balance sheets and have tremendous political repercussions. The fiscal fall-out from the global financial crisis of 2007/08 will shape the political agenda in Europe for years to come. In their prescient book from 2009, Carmen Reinhart and Kenneth Rogoff described the historical regularity with which private sector financial crises tend to be followed by sovereign debt crisis in emerging markets. ${ }^{1}$

In this paper, I examine the impact that financial crises had on public debt over the past 140 years. Unlike much of the previous literature, this paper focuses on the experience of 14 industrial countries over the long run. I do not look at emerging market economies and my aim is to leave the narrow focus on the post-1960 decades, dominant in the economic literature, to study how the interaction of financial crises and government stabilization policies evolved over the long run. Moreover, I combine trends in public debt with detailed annual data on the growth of the financial sector, which have become available recently. ${ }^{2}$ This allows me to ask if and how the costs of financial crises vary with the size of the financial sector.

The main findings of this paper include the following. First, I demonstrate that the budgetary costs of financial crises are large and have increased strongly in the course of the past 140 years. In the post-WWII era, public debt to GDP ratios typically rose by one third or about 20 percentage points of GDP in the five years after a systemic financial crisis. By contrast, prior to WWII, public debt ratios were by and large unaffected by financial crises. 
Second, I present evidence suggesting that the fiscal costs of financial crises have grown as financial sectors have become larger. In economies with large financial sectors, the cumulative increase of public debt to GDP following a banking crisis reaches $50 \%$ on average. This figure does not yet include the experience of the 2008 global financial crisis whose fiscal costs could be even higher - for instance, according to forecasts of the International Monetary Fund, both the US and the UK will see their debt to GDP ratios double as a result of the crisis. ${ }^{3}$

Third, I argue that these findings add an important new element to conventional narratives of public debt dynamics in the twentieth century. While historically public debt dynamics in the Western world have reflected the costs of fighting major wars, the debt buildup in the second half of the twentieth century stands out as the first marked increase of public sector debt ratios in peacetime. ${ }^{4}$ The rising fiscal costs of financial crises have played an important role in this development. In many countries, major financial crises were key factors behind the worsening of public debt trajectories. In this respect, the rise in the level of public debt in the last decades of the twentieth century is not solely a reflection of generous welfare programs or costly economic policies by spendthrift governments. The spectacular growth of the financial sector and the increasingly large fiscal costs of financial crises played an important, and in some cases a dominant role. The link between the size of the financial sector and the fiscal fall-out from crises should be taken into account in the current debate about the causes of high public debt and the regulation of the financial sector.

From both an economic and political point of view, one can question the wisdom of government activism in the wake of financial crises. Especially the economic effects of stimulus programs remain hotly debated amongst economists. Yet from a historical point of view, it is clear that governments have typically decided that increasing fiscal deficits in order to mitigate the economic effects of financial crises is a political necessity. The 2008 crisis was another landmark event in this long trajectory. Alessandri and Haldane argue that the scale of intervention to support the banks has exceeded any previous levels of state assistance. ${ }^{5}$ Counting all liquidity and capital injections, debt guarantees as well as deposit insurance and asset purchases, they calculate that the total size of interventions in the Eurozone, the United Kingdom and the USA amounted to about \$14 trillion or a quarter of global GDP - an unprecedented mobilization of the public sector balance sheet to deal with the consequences of a financial crisis. In addition to these direct guarantees and capital injections - which should not be confused with actual losses for the taxpayer that are likely to be much smaller - 
come the economic and fiscal costs of the crisis: large and persistent budget deficits, burgeoning public debt ratios and large output losses.

But why have the fiscal costs of financial crises increased so strongly in the twentieth century? In the last section of this paper, I take a closer look at the revenue and expenditure dynamics around financial crises. I find evidence that financial crises take a heavier toll on public revenues when the size of the financial sector is large. Crises in more highly financialized economies tend to have more severe effects on the revenue base and therefore go hand in hand with much costlier post-crisis stabilization efforts. These results mesh with previous research that has shown that the economic effects of crises tend to be a function of the previous credit expansion and the level of financialization. ${ }^{6}$

From a historical perspective, the main findings of this study can be rationalized by the fundamental shift in relations between the state and the financial sector that has taken place in the course of the twentieth century. The birth of active government stabilization policies to fight financial crises dates back to the Great Depression. ${ }^{7}$ The Depression was a watershed event for macroeconomic thinking and policymaking. The 1930s showed that the costs of doing nothing in the face of systemic banking sector instability were unbearably high - both in economic and political terms. As a consequence, most countries introduced publicly guaranteed deposit insurance schemes and established other tools to prevent the financial sector from collapsing in times of stress.

Through these policies the state assumed a new role - that of guaranteeing the integrity of the financial system. Financial stability became a quasi-public good and the liabilities of the banking sector became implicitly or explicitly guaranteed by the government. In times of crises, the public sector balance sheet could be mobilized to temper the consequences of financial instability and support the real economy through deficit spending. Yet as Alessandri and Haldane argue, there was also another side of this implicit depression era "social contract" between the state and the financial sector: tight financial regulation. ${ }^{8}$ The Glass-Steagall Act of 1933 in the USA is the best example illustrating this two-sided arrangement. In exchange for public backstops for the financial sector in the form of deposit insurance through the Federal Deposit Insurance Corporation, the act established a set of financial regulations including the separation of commercial and investment banking that became characteristic of the US banking system until the separation was dismantled again in the 1990s. The economic logic behind stricter regulation was clear. As the state became the ultimate guarantor of the liabilities of the financial sector, the government had to be able to 
control the accumulation of risks in the financial sector. In other words, regulation was the quid pro quo of deposit insurance and other public sector guarantees for the financial sector.

However, as the memory of the Depression faded, this tight regulatory regime was incrementally dissolved. Financial deregulation and liberalization in the 1970s and 1980s freed the financial sector from many earlier limits with regard to its size and capacity for financial risk taking. Yet while one side of the Depression era "contract" between governments and the financial sector dissolved, the other side did not. Finance was increasingly free from regulatory constraints, but the public sector remained the guarantor of last resort in times of crisis. The contract became one-sided and a large chasm opened up: governments remained responsible for an ever-larger financial sector whose behavior was more and more withdrawn from public oversight.

It is even possible if not likely that implicit government guarantees might themselves have been a key cause of the extraordinary growth of the financial sector in the second half of the twentieth century. It is possible that the financial sector grew so large after the 1970s partly because of implicit and explicit government backstops that provided a safety cushion for banks. As rational economic actors, financial institutions have anticipated the government response to financial crises, increased their risk taking and lowered capital buffers. The financial sector has begun to "bank on the state." ${ }^{9}$ In a similar vein, I have demonstrated elsewhere with Alan Taylor that central bank's reaction function to financial crises has changed dramatically after WWII. ${ }^{10}$ Through policy interventions, central banks in the postWWII period have prevented a contraction of the money supply, deflation and rapid financial deleveraging. But the very success of central banks in moderating the fall-out from financial crises might have encouraged risk-taking on an ever-greater scale.

These questions are not easily disentangled and not all questions can be answered with the data at hand. The main purpose of this paper is therefore to provide an empirical backbone for the ongoing debate. My aim is to present a few key stylized facts about the macroeconomic history of financial crises. I will concentrate on the question of how large the costs of crises have been at different times and under different policy regimes - from the gold standard until today - and pay particular attention to the question of how the costs of financial crises relate to the size of the financial sector.

The structure of the paper is as follows. I first sketch out the debate about the costs of financial crises. In the second section, I briefly discuss the data sources and the key concepts and definitions I work with. The third part of the paper is devoted to a discussion of long-run trends in public debt in the Western world from the late nineteenth century until today. The 
fourth part then considers the interaction of financial crises and public debt. The fifth part looks in greater detail at the effects of crises on government revenues and expenditures. The final section offers some concluding remarks.

\section{The costs of financial crises}

That financial crises have substantial costs for the real economy is now widely acknowledged. Recent studies by Cerra and Saxena, Reinhart and Rogoff, as well as Reinhart and Reinhart and Jorda, Schularick and Taylor have provided ample evidence supporting the idea that financial crises have long-lasting negative effects on output. ${ }^{11}$ Cerra and Saxena find that financial crises lead to output losses in the range of 7.5\% of GDP over ten years. Reinhart and Rogoff calculate that the historical average of peak-to-trough output drops following banking crises is about $9 \%$. Teulings and Zubanov also estimate an output loss of $10 \%{ }^{12}$ In addition, Kroszner, Laeven and Klingbiel argue that crises in larger financial systems are associated with stronger macroeconomic effects. ${ }^{13}$ Using long-run historical data, Jorda, Schularick and Taylor basically confirm the plausibility of these estimates. ${ }^{14}$ While the presence of longlasting negative output effects of financial crises seems well established (and seems born out by the sluggishness of the current recovery), the wider public as well as financial markets have become more and more concerned with a different fall-out from financial crises: the fiscal costs of crises.

The notion that financial crises tend to be associated with a significant deterioration of government balance sheets is not new. ${ }^{15}$ The combination of weaker economic growth and lower revenues as well as an increase in government expenditures linked to direct bailout costs and stimulus programs widens deficits and thereby increases the existing government debt. ${ }^{16}$ Reinhart and Rogoff argue that a strong link exists between banking crises, the subsequent increase in public debt and sovereign defaults. ${ }^{17}$ Focusing on the major postWorld War II episodes, they assert that even absent large costs associated with bailing out and recapitalizing the banking system, government debts rise about 86 percent relative to precrisis levels in the three years following a systemic banking crisis. In their analysis, the main driver of the increase in public debt is the collapse in tax revenues arising from deep and prolonged output contractions. In addition, rising interest rates on government debt as well as fiscal stimulus programs contribute to the post-crisis debt surge. ${ }^{18}$ However, as their sample contains many emerging market crises, it is not clear to what extent the findings are also applicable for the OECD countries. 
In related work, Furceri assumes a wider perspective and analyzes a sample of 28 OECD economies over the period 1970 to $2008 .{ }^{19}$ He finds that financial crises on average lead to a permanent increase in the government debt to GDP ratio of 6 percentage points (ten years after the financial crisis). The occurrence of a "severe crisis" resulted in an increase of 32 percentage points in the debt to GDP ratio. Furceri and Zdienicka widened this analysis to a sample of 154 countries in the period 1970 to $2006 .{ }^{20}$ Their study confirms that banking crises are associated with a substantial and enduring increase in the public debt to GDP ratio. For severe crises, they find an increase of up to 50 percentage points at the peak and by about 37 percentage points over the medium term - that is eight years after the crisis started. Moreover, they find that the magnitude of this effect also depends on various initial conditions such as the debt to GDP ratio as well as the size of foreign debt shares that a country holds.

Finally, as part of major research undertaken at the International Monetary Fund, Abbas et al. collected data on gross government debt-to-GDP ratios covering 174 countries starting in $1880 .^{21}$ Abbas et al. show that the negative impact of the 2008 crisis on public debt has been much worse than in the Great Depression, albeit the output costs have been smaller potentially because of larger government interventions. In the current crisis, governments have applied the lessons of the Great Depression and assumed more active roles in the face of financial disruptions.

A related body of literature is concerned with the economic effects of high public debt levels. It was again the influential work of Reinhart and Rogoff that stimulated the debate. ${ }^{22}$ The key question is whether high public debt levels might affect economic growth negatively through higher interest rates or lower private sector confidence. Reinhart and Rogoff find that economic growth is negatively affected once public debt to GDP levels cross the $90 \%$ level this figure has been quoted often in the media. Checherita and Rother as well as Kumar and Woo have also found evidence of slower growth when public debts are high. ${ }^{23}$ Leaving the difficult issues of reverse causality aside - low growth could be the reason for high public debt - there continues to be disagreement about the validity of the original numbers presented by Reinhart and Rogoff.

On closer inspection, it turns out that their findings depend upon the inclusion of the immediate post-WWII years. During 1946 and 1947, the US and other economies saw deep recessions because of transition from the war to a peacetime economy. During this transition public debts were high because of the budgetary costs of the war effort. But it is questionable whether these special episodes should be used to construct a causal argument about the impact 
of high public debts on economic growth. As figure 1 demonstrates, there is hardly any difference in average growth rates at high or low levels of public debt if the postwar recessions are omitted. ${ }^{24}$ The figure shows average rates of growth at different levels of public debt over GDP since 1880. Excluding the immediate war and postwar years (1914-1920; 1939-1947), no relationship between public debt levels and growth is visible.

\section{[Figure 1 here]}

Public Debt Ratios and Growth, 1880-2008

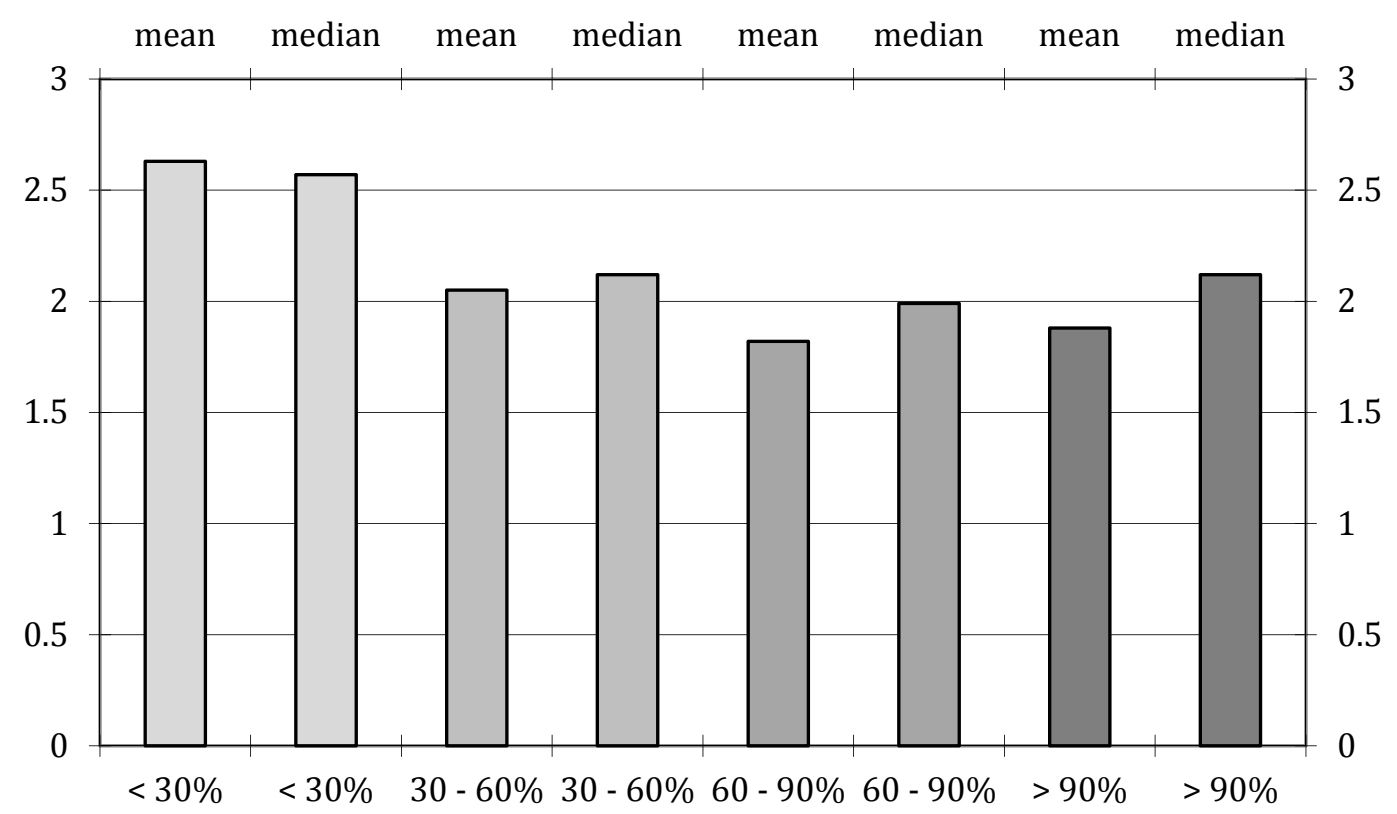

Note: average for 14 advanced countries: Australia, Canada, Denmark, France, Germany, Great Britain, Italy, Japan, Netherlands, Norway, Spain, Sweden, Switzerland, United States.

Figure 1. Public debt and growth, 1880-2008

\section{Data and definitions}

For a more detailed investigation of the relationship between financial crises and public debt, some terms and definitions need to be clarified upfront. The first important definitional issue concerns financial crises per se. There is no simple definition of financial crises. Moreover, the timing of historical crises can be controversial. In line with previous studies, I define a financial crises as an event during which a country's financial sector experiences a bank run or a sharp increase in default rates accompanied by large losses of capital. These developments then result in public intervention, bankruptcy, or forced merging of financial institutions. $^{25}$ 
On the basis of this definition, I have presented a consensus timing of financial crises in the past 140 years for a sample of 14 countries in a joint paper with Jorda and Taylor. ${ }^{26}$ We studied the following countries: United States, Canada, Australia, Denmark, France, Germany, Italy, Japan, the Netherlands, Norway, Spain, Sweden, Switzerland, and the United Kingdom. Compiling this list, we received help from a large number of other financial historians around the world. Each individual crisis date for the pre-1940 era was doublechecked by country experts. For the post 1960-period, banking crises histories are based on the database compiled by Laeven and Valencia. According to this definition, between 1870 and 2010, 79 systemic financial crises occurred in the 14 industries countries studied here. Table 1 summarizes this definition of crises events by country-year.

\section{[Table 1 here]}

Table 1: Financial Crisis Dates

\begin{tabular}{|c|c|c|c|c|c|c|c|c|c|}
\hline Australia & 1893 & 1989 & & & & & & & \\
\hline Canada & 1873 & 1893 & 1907 & 1923 & 1985 & & & & \\
\hline Switzerland & 1870 & 1910 & 1931 & 2008 & & & & & \\
\hline Germany & 1873 & 1891 & 1901 & 1907 & 1931 & 2008 & & & \\
\hline Denmark & 1877 & 1885 & 1902 & 1907 & 1921 & 1931 & 1987 & & \\
\hline Spain & 1883 & 1890 & 1913 & 1920 & 1924 & 1931 & 1978 & 2008 & \\
\hline France & 1882 & 1889 & 1907 & 1930 & 2008 & & & & \\
\hline U.K. & 1873 & 1890 & 1974 & 1984 & 1991 & 2007 & & & \\
\hline Italy & 1873 & 1887 & 1891 & 1907 & 1921 & 1930 & 1935 & 1990 & 2008 \\
\hline Japan & 1882 & 1900 & 1904 & 1907 & 1913 & 1927 & 1992 & & \\
\hline Netherlands & 1893 & 1907 & 1921 & 1934 & 1939 & 2008 & & & \\
\hline Norway & 1899 & 1922 & 1931 & 1988 & & & & & \\
\hline Sweden & 1878 & 1907 & 1922 & 1931 & 1991 & 2008 & & & \\
\hline USA & 1873 & 1884 & 1893 & 1907 & 1929 & 1984 & 2007 & & \\
\hline
\end{tabular}

Source: Jorda, Schularick, Taylor (2011)

Looking at the incidence of financial crises in the past 140 years, it becomes clear very quickly that their frequency has varied substantially. Before the Second World War, financial crises were relatively frequent - possibly owing to the absence of a lender of last resort in many countries, e.g., in the USA. The immediate post-WWII decades by contrast were a financial oasis of calm. Domestic financial regulation was tight and the Bretton-Woods System restricted international capital movements. As a matter of fact, no big financial crisis occurred in the 30 years between 1945 and 1974. From the mid-1970s on, financial instability returned. Financial deregulation and international capital market integration are likely to have played a role in this process. ${ }^{27}$ Figure 2 displays the number of countries (out of the 14 country sample) that witnessed a systemic financial crisis in any given year since 1870 . 
[Figure 2 here]

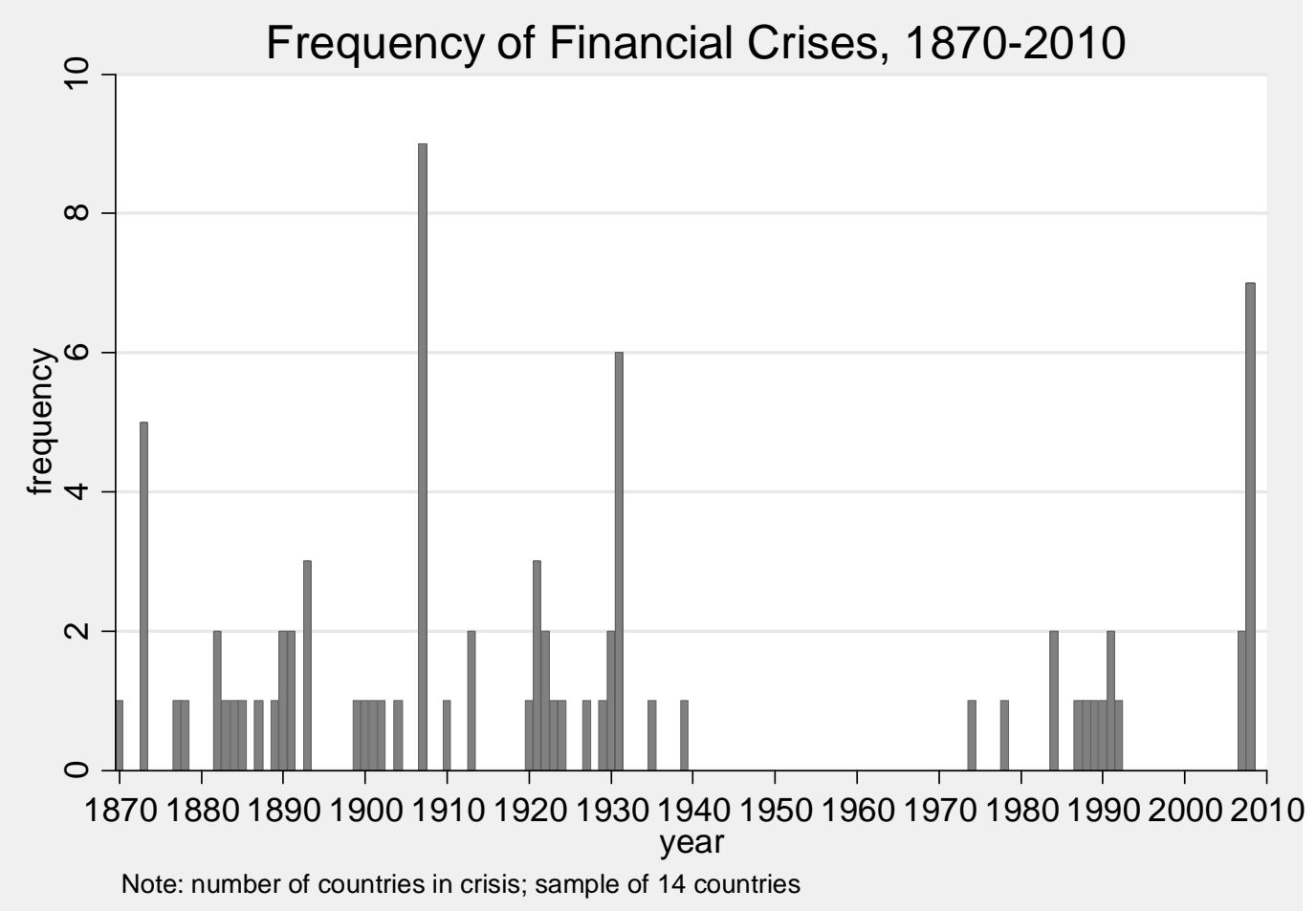

Figure 2. Frequency of financial crises, 1870-2010

Also with regard to the public debt data, a number of initial clarifications are necessary. The data used here come from the historical public debt database compiled by Abbas et al. at the IMF. ${ }^{28}$ The data are accessible via the Internet and aim to cover the consolidated general government, i.e. all levels of governments. I have doubled checked these data against traditional historical sources such as Mitchell's Historical Statistics and generally found the data to be reliable. Some issues remain with regard to the treatment of local government debt and various other liabilities, but these are unlikely to change the picture dramatically. Private debts of individual monarchs as well as future liabilities of governments such as pension liabilities are not included. The data cover the level of public debt to GDP at annual frequency. For most of the countries covered here, the data start around 1870 or 1880 but some important gaps remain. Taken together with the crisis dates described above, the historical public debt database allows for a long-run study of the fiscal impact of financial crises in the western world since the late nineteenth century. 


\section{Long-run trends in public debt}

I will begin by describing some general trends with regard to the development of public debt to GDP trend that are evident in the data. Figure 3 displays the development of public debt to GDP ratios (as mean and median) for the 14 countries for which we have a detailed body of historical financial data. The first impression is that current levels of government debt in advanced economies are high, but not extraordinarily so. Current levels of debt to GDP are comparable to those reached in the 1920s, but still considerably below the very high levels of debt incurred during WWII. The chart also shows common movements in the public debt to GDP ratio across countries since the late nineteenth century. In four periods, public debt ratios increased significantly: in the First World War, during the Great Depression, then again in the Second World War, and finally in the three decades since the late 1970s.

The First World War drove up public debt ratios to about $70-80 \%$ of GDP. ${ }^{29}$ During the boom of the 1920s, government balance sheets improved slightly, but this trend quickly reversed when the Great Depression hit. Public debt to GDP ratios rose, not only because deficits increased as revenues slumped, but also because the denominator, GDP, fell sharply in many countries. The depression underlines a simple but important point about public debt dynamics - both the numerator and the denominator merit attention.

The military effort for the Second World War led to spiraling public debt levels in most countries. At the end of the conflict, both the mean and the median reached around $100 \%$ of GDP for the victorious countries. These high public debt levels were no major obstacle to the postwar economic boom. This being said, in the defeated axis powers, internal debts were generally wiped out so that these countries started from low levels. For the entire 14-country group, the postwar era was characterized by a marked reduction of public debt to GDP ratios. The pre-World War I levels of about 40-50\% of GDP were reached again in the 1960s.Another upward trend started in the late 1970s and lasted to the 1990s. In the mid1990s the interwar levels of public debt to GDP were reached again in the majority of countries as debt levels crossed the 60\% mark. After a brief stabilization in the late 1990s and early 2000s, the upward trend that was visible since the 1970s accelerated in recent years following the global financial crisis and the ensuing recession. ${ }^{30}$

Ritschl has argued, this peacetime run-up in public debts has no precedent in modern history. ${ }^{31}$ Virtually all major changes in debt trajectories in the modern era were linked, in one way or the other, to the cost of financing major wars. Ritschl notes that this raises the possibility that a regime shift has taken place in the late twentieth century with potentially problematic implications for debt sustainability. Yet the question remains open as to what the 
new drivers of public debt increases in the second half of the twentieth century were. Can the surge in the debt ratio be traced back to a general slowdown in the growth rate of Western economies and the inability of politicians and governments to adjust generous spending programs to the new reality? Or have other factors played an important role too? I will argue below that the fiscal costs of financial crises are an important aspect of this story.

\section{[Figure 3 here]}

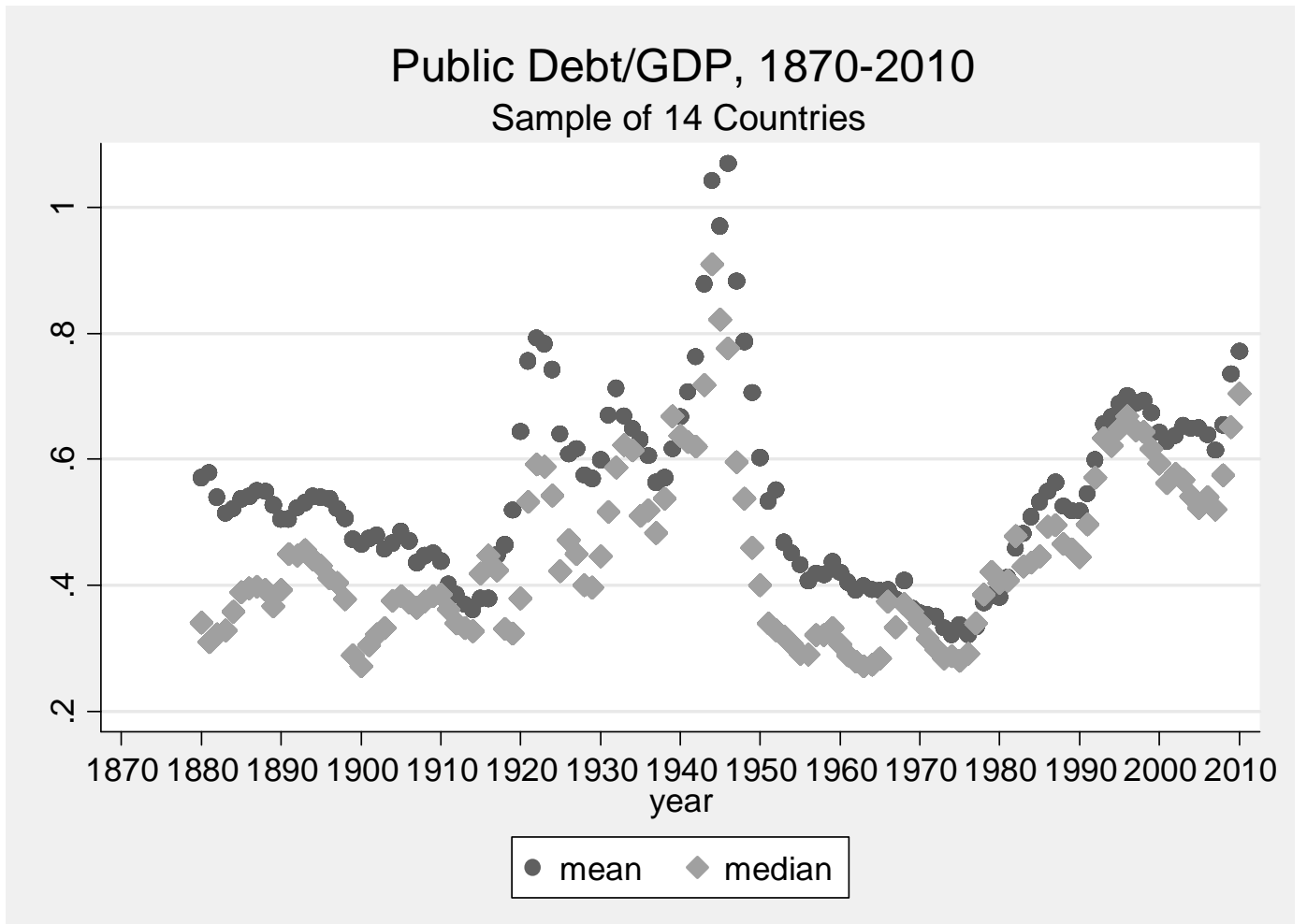

Figure 3: Public Debt/GDP, 1870-2010. Sample of 14 countries.

\section{The fiscal costs of financial crises}

In what follows, I will bring together the datasets on financial crises and public debt discussed above. The basic approach will be akin to a classical event study approach. In other words, I will analyze how the public debt to GDP ratio typically changes in the years after a financial crisis event has occurred. I start by looking at summary statistics before breaking the analysis down and looking at the effects of crises on public debt relative to individual country trends. The key results remain the same across the various ways to make the data speak: Financial crises are costly for the public sector. The costs have risen considerably over the course of the twentieth century. Moreover, there is evidence that the costs of financial crises are linked to the size of the financial sector. 
Table 2 opens the discussion by showing a broad picture of the average annual increase in the public debt to GDP ratio in the five years after a financial crisis. The upper panel shows that pooling all countries the average annual increase of the public debt to GDP ratio following a financial was about 83 basis points. Multiplying the figure by 6 (the crisis year plus the following five years) gives a baseline estimate of about 5 percentage points. In other words, over the past 140 years financial crises have on average led to a deterioration of the public debt to GDP level by roughly 5 percentage points. However, this summary measure hides as much information as it reveals. This is because in the pre-WWII period, financial crises had hardly any effect on public debt ratios. Yet after WWII, the deterioration is on average 330 basis points per year - or around 20 percentage points five years after the crisis.

The pronounced effect of financial crises on public debt ratios becomes clearer when compared to the remaining years (outside the crisis window). In the post-1975 period, public debt ratios increased by about 90 basis points per year on average. After 20 years, public debt to GDP will increase by around 18 percentage points, certainly a very significant increase. Yet this effect pales in comparison with the speed with which public debt ratios balloon after a financial crisis. The average deterioration is about 3.5 percentage points per year in years 0 5 of a financial crisis episode. Put differently, financial crises have become a major driver of public debt trajectories for the affected countries.

Combining the information on public debt and crisis dates with data for the size of the financial sector - measured by the total outstanding amount of credit to the private sector relative to GDP - allows us to go one step further and check whether the fiscal costs of crises vary with the size of the financial sector. The lower panel of table 2 suggests that it does. The increase of public debt in more financialized economies, i.e., those with larger financial sectors, is more than twice as high. If private sector to credit to GDP is below the sample mean of 70\%, public debt to GDP increases by a little more than 2 percentage points post1975 in the wake of a financial crisis. If a crisis strikes an economy with a large financial sector, the effect grows to nearly 5 percentage points implying a deterioration of the public debt to GDP ratio of close to 30 percentage points over the following 5 years. These estimates rely on about 40-50 observations per group and about 90 post-WWII yearly observations.

At first sight, these effects might seem implausibly large. A deterioration of 30 percentage points of GDP would mean that the public debt to GDP ratio increases from, say, $50 \%$ of GDP to $80 \%$ within half a decade on average. Moreover, a 30 percentage point increase in the public debt to GDP ratio roughly corresponds to the increase in public debt witnessed across the western world since the late 1970s, as discussed above. Whether a 
country had a financial crisis or not might account for the largest part of the deterioration in public levels. Does this sound realistic? On a closer look, this is exactly what the individual country experiences tell us. Following the Swedish banking crisis in 1991, the public debt ratio went from 55\% in 1991 to 83\% of GDP in 1997; following the Spanish financial crisis of 1978, public debt went from 12\% of GDP to 37\%; and in the 2007 crisis, the UK had a public debt to GDP ratio of $43 \%$ in 2007 which will have risen to more than $80 \%$ by the end of 2011 - four years after the crisis. The conclusion is simple: in the developed world today, financial crises are a key health risk for public finances.

\section{[Table 2 here]}

Table 2: Financial Crises and Public Debt Changes

Percentage point change of the debt/GDP ratio

\begin{tabular}{lcccc}
\hline \hline & Post crisis* & $\mathrm{N}$ & Normal & $\mathrm{N}$ \\
\hline All years & 0.83 & 362 & 0.19 & 1149 \\
Pre-WW2 & -0.04 & 267 & 1.16 & 495 \\
Post-WW2 & 3.31 & 95 & -0.43 & 705 \\
Post-1975 & 3.46 & 93 & 0.88 & 378 \\
\hline Post-1975 and small financial sector* & 2.27 & 52 & & \\
Post-1975 and large financial sector & 4.96 & 41 & & \\
\hline
\end{tabular}

Note: The figures shown represent the average annual change of the ratio of public debt over GDP in the first five years after a financial crisis; financial sector are large (small) when the credit to GDP ratio is above (below) $70 \%$ which is the sample mean.

As a next step, I will subject these summary statistics to further statistical tests. Two possible factors seem particularly important to include. First, different countries could have very different long-run public debt trajectories or show different responses to financial crises for political or institutional reasons. In other words, any study of the fiscal effects of financial crises has to allow for systematic differences between countries. Second, countries might share common trends in the development of their public debt ratios - the simultaneous increase after the 1970s comes to mind. Financial crises might coincide with periods of marked increases in public debt across countries. Also such common shifts across countries need to be controlled for.

Table 3 shows the change in the public debt to GDP ratio following financial crises, accounting for country-specific trends and common time effects. The effects are now expressed as cumulative (log-) level changes so that the percentage effects over a 5-year period after the crisis can be read directly from the coefficients. The most important point here is that table 3 basically confirms the key insights gained earlier. Looking at the entire 
period from 1870 to 2010, public debt ratios increased by about 13\% in the years following financial crises with high statistical significance. Yet the same dichotomy that we have encountered earlier is again visible. Before WWII, the increase is very small (3\%) and statistically not significant. The real story is that after WWII, financial crises have typically triggered a massive deterioration in public debt ratios of more than $30 \%$. As we had seen before, the effects are particularly pronounced when crises occur in large financial sectors. In post-1975 financial crises, public debt levels jump by nearly 50\% relative to a country's trend when the financial sector is large relative to the real economy. Needless to add, these effects easily pass standard statistical significance test at 99\% significance levels.

\section{[Table 3 here]}

\begin{tabular}{|c|c|c|c|}
\hline & Coefficient & Standard error & t-value \\
\hline All years & $0.13^{* * *}$ & 0.04 & 3.08 \\
\hline Pre-WW2 & 0.03 & 0.06 & 0.53 \\
\hline Post-WW2 & $0.31^{* * *}$ & 0.07 & 4.15 \\
\hline Post-1975 & $0.32^{* * *}$ & 0.07 & 4.61 \\
\hline Post-1975 and large financial sector & $0.48^{* * *}$ & 0.13 & 3.73 \\
\hline
\end{tabular}

Where do these results leave us? First, the fiscal costs of financial crises have clearly increased over time, however measured. Before WWII, fiscal policy was by and large irresponsive to financial crises and their real economic effects. After WWII, governments have routinely expanded fiscal deficits to deal with the consequences of financial crises. The resulting increase of public debt ratios was considerably larger than before. Second, the costs of these interventions appear to vary with the size of the financial sector. Financial crises are costlier in more highly financialized economies. Third, in the light of these results financial crises have played an important role in the rapid peacetime increase of public debt in the late twentieth century. For the ten countries (out of the 14 in the sample) that witnessed financial crises in the last 40 years, the average effect was to drive up public debt to GDP ratios by a cumulative $30-50 \%$, depending on the size of the financial sector. These effects are not only statistically significant but also economically large and account for a dominant part of the post-1970 debt increase.

For most of modern history, wars were the most significant drivers of public debt dynamics in the western world. ${ }^{32}$ By contrast, financial crises generally did not leave a big 
imprint on trends in public debt until the second half of the twentieth century. Yet, during the last quarter of the twentieth century financial crises have shaped public debt trajectories in a major way and arguably more so than other developments. As the figures in table 2 demonstrate, the increase of public debt ratios outside the financial crisis episodes was much more subdued. For the 14 country sample studied here, public debt to GDP ratios rose by less than 90 basis points per year in "normal" times, compared to close to 350 basis points after financial crises. Any history of public debt that does not account for the important role of financial crises in affecting public debt trajectories in the late twentieth century would be highly incomplete.

\section{Effects of crises on public revenues and expenditures}

Why have the costs of financial crises increased so strongly during the second half of the twentieth century? It is likely that two different dynamics were at work. On the one hand, governments have generally taken a much more active role in managing the business cycle in the second half of the twentieth century. As is well known, macroeconomic policies that steer aggregate demand not only through monetary policy, but also through deficit spending have grown in importance. As financial crises often go hand in hand with recessions, the larger fiscal costs of financial crises in the post-1945 world to some degree reflect the fiscal costs of fighting the ensuing recessions. Second, in the second half of the twentieth century the financial sector has grown strongly relative to the real economy. For a given level of government intervention in the economy, crises appear to be costlier if the financial sector is large. Crises in more highly financialized economies seem to take a heavier toll on the real economy and lead to larger fiscal deficits in the years following the crisis.

Figure 4 illustrate the extraordinary growth of the financial sector relative to the real economy in the 14 countries studied here. ${ }^{33}$ Faced with this historically unprecedented growth of financial intermediaries, it comes as little surprise that the frequency of financial crises has increased again. Liberalization and deregulation make banking freer but potentially more vulnerable to crisis. ${ }^{34}$ More highly financialized economies seem to run a greater risk of incurring financial crisis. ${ }^{35}$ Just as more leveraged companies run a higher risk of bankruptcy when the business cycle turns, more leveraged financial systems are more vulnerable to financial or real shocks. But a higher probability of incurring a financial crisis is not the only worry for the government when the financial sector is large - also the fiscal costs of crises seem to grow when they happen. 
[Figure 4 here]

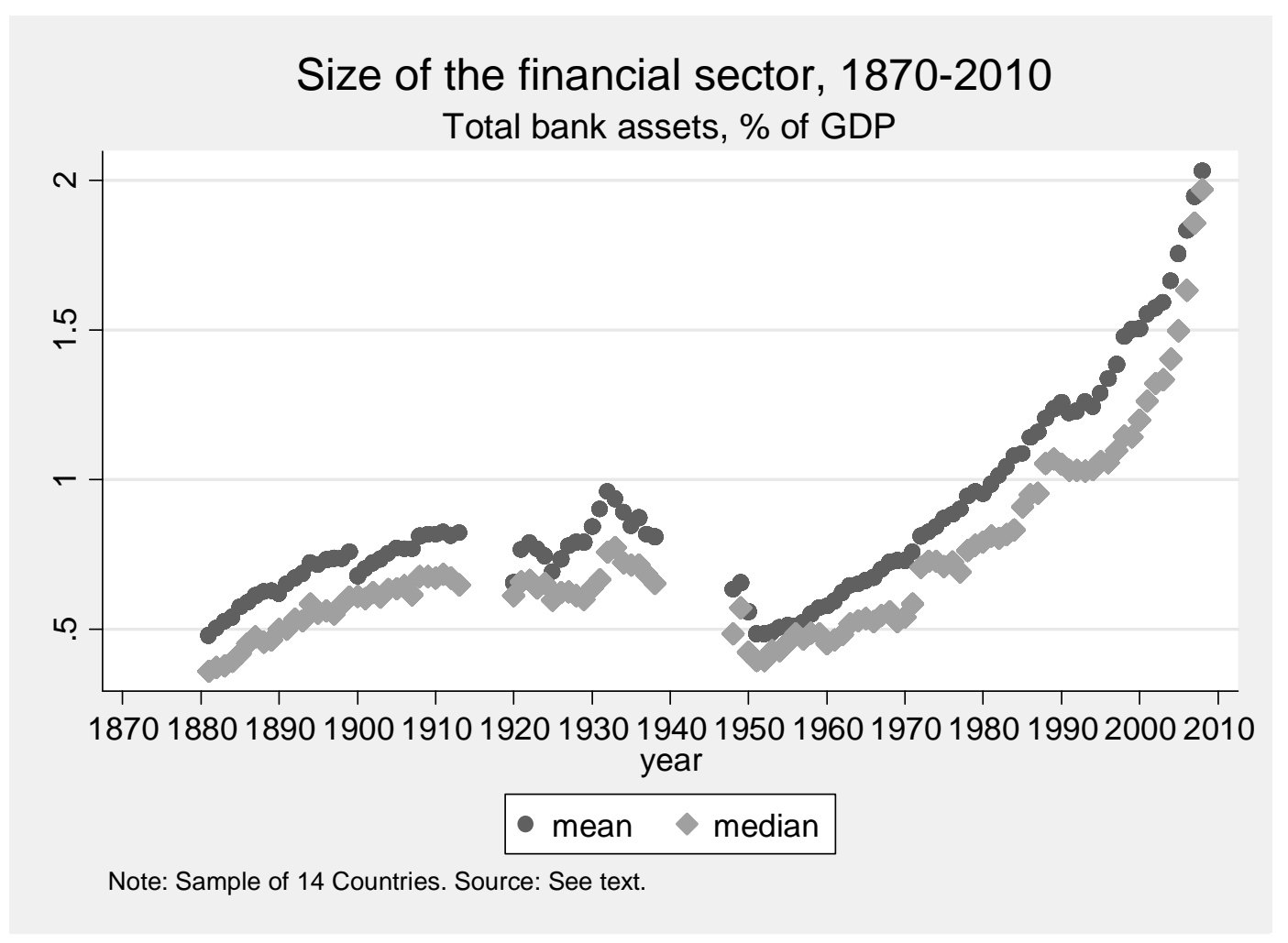

Figure 4. Size of the financial sector, 1870-2010.

We can say a little more about the reasons behind the increasing fiscal costs of crises in highly financialized economies by studying how crises affect revenues and expenditure. In table 4, I repeat the earlier exercise and look at the cumulative change of revenue and expenditure (in real terms over the five years following a crisis) relative to long run, countryspecific trends. Put differently, I ask how a financial crisis "changes" the long run patterns in the growth rate of real government revenues and expenditures. In a second step, I repeat the same analysis but look at the effects of high and low levels of financialization. As it turns out, the differences in the post-crisis behavior of these indicators are large.

[Table 4 here] 
Table 4: Effects of Financial Crises on Revenues and Expenditures

Cumulative log level change 5 years after crisis, vs. trend

\begin{tabular}{lccc}
\hline \hline Real government revenue & Coefficient & Standard error & t-value \\
\hline All years & $-0.13^{* * *}$ & 0.03 & -3.96 \\
Pre-WW2 & $-0.09^{*}$ & 0.05 & -1.90 \\
Post-WW2 & $-0.09^{*}$ & 0.05 & -1.79 \\
All years, large financial sector & $-0.18^{* * *}$ & 0.05 & -3.45 \\
Pre-WW2, large financial sector & $-0.14^{*}$ & 0.07 & -1.81 \\
Post-WW2, large financial sector & $-0.19^{*}$ & 0.11 & -1.82 \\
\hline Real government expenditure & & & \\
\hline All years & -0.07 & 0.05 & -1.52 \\
Pre-WW2 & -0.07 & 0.08 & -0.86 \\
Post-WW2 & 0.03 & 0.06 & 0.50 \\
All years, large financial sector & -0.07 & 0.08 & -0.87 \\
Pre-WW2, large financial sector & -0.03 & 0.12 & -0.26 \\
Post-WW2, large financial sector & -0.04 & 0.12 & -0.35 \\
\hline
\end{tabular}

Note: Regression includes country fixed effects and a common time trend; ${ }^{* * *}$ Denotes significance at the $99 \%$ level, $* * 95 \%$ level, and $* 90 \%$ level.

The results presented in table 4 paint an interesting picture. The predominant effect of financial crises is to depress government revenue. As for government expenditure, the effects are much smaller and much less precisely estimated. If anything, it seems that government expenditure falls in the five years following a financial crisis, but by an economically and statistically insignificant amount. It is hence not the increase in expenditure, but the pronounced decline in revenue that makes financial crises so costly for public accounts. ${ }^{36}$

More importantly, table 4 also helps us answer the question as to why the public debt effects of financial crises tend to be considerably larger when a crisis occurs in a highly financialized economy. The reason is that the cumulative shortfall in revenues is about twice as high in the post-WWII period (19\% vs. $9 \%$ ) and about $50 \%$ higher for the entire sample (19\% vs. $13 \%)$ when the financial sector is large. ${ }^{37}$ Moreover, this is not simply a pre-WWII vs. post-WWII story. The same difference is apparent in pre-WWII and post-WWII data separately: in both periods financial crises tend to lead to sharper revenue declines when the financial sector is larger. These results mesh with recent findings that that credit booms lead to more severe recessions when the financial sector is big. ${ }^{38}$

\section{Conclusion}

This paper attempts to demonstrate that over the past century financial crises have taken an increasingly large toll on public finances. Financial crises have become a major risk for the 
sustainability of public finances. In today's large financial systems, a financial crisis will typically lead to a $50 \%$ deterioration of the public debt to GDP ratio from the initial level. To make things concrete, the pre-crisis sample average of public debt to GDP was a little above $60 \%$ of GDP. The results obtained here imply that the financial crisis can be expected to increase this ratio to between $80 \%$ and $90 \%$ of GDP, depending on the size of the financial sector. It may well turn out that these estimates, relying on past data for smaller financial sectors, prove too optimistic.

In any case, it is clear that the potential fiscal fall-out from financial crises represents a major contingent liability of the public sector. Clearly, the validity of these estimates depends on the assumption that financial crises can be treated as "exogenous" shocks, unrelated to the fundamentals of the economy. In the real world, very few things are truly exogenous and the relationships much more intertwined and complex: crises don't just happen; they build up over many years. In this sense, it is clearly possible that underlying trends account both for the occurrence of a financial crises and for the subsequent effects on the real economy and fiscal accounts.

However, there seems to be at least relatively strong prima facie evidence for a close link between financial liberalization, the frequency and severity of crises and the massive deterioration of government balance sheets. From a policy perspective, these connections appear too strong to ignore and should be taken into account when it comes to the regulation of the financial sector and a comprehensive assessment of the risks and benefits of the growth of the financial sector in recent decades. 


\section{Notes}

${ }^{1}$ Reinhart and Rogoff, This Time is Different. Economists have also started to look closer at the links between private sector crises and public sector debt accumulation. A recent paper by Acharya, Drexler and Schnabl, “A Pyrrhic Victory?” was motivated by the Irish bank rescue operations that brought the state to the brink of bankruptcy. It spells out a potential mechanism linking private sector financial instability and subsequent public sector debt crises.

${ }^{2}$ See Schularick and Taylor, "Credit Booms Gone Bust."

${ }^{3}$ See the projections in the September 2011 World Economic Outlook Database of the International Monetary Fund.

${ }^{4}$ Ritschl, "Sustainability of High Public Debt;” Hamilton, "Origin and Growth.”

${ }^{5}$ Alessandri and Haldane, "Banking on the State."

${ }^{6}$ Jorda, Schularick and Taylor, "When Credit Bites Back."

${ }^{7}$ Bordo et al., The Defining Moment.

${ }^{8}$ Alessandri and Haldane, "Banking on the State."

${ }^{9}$ Alessandri and Haldane, "Banking on the State."

${ }^{10}$ Schularick and Taylor, "Credit Booms Gone Bust."

${ }^{11}$ Cerra and Saxena, "Growth Dynamics;" Reinhart and Rogoff, "The Aftermath of Financial Crises;” Reinhart and Reinhart, “After the Fall;” Jorda, Schularick and Taylor, "Financial Crises.”

${ }^{12}$ Teulings and Zubanov, "Is Economic Recovery a Myth?”

${ }^{13}$ Kroszner et al., "Banking Crises."

${ }^{14}$ Jorda, Schularick and Taylor, "When Credit Bites Back."

${ }^{15}$ Horton et al., "The State of Public Finances."

${ }^{16}$ Nickel et al., "Major Public Debt Reductions."

${ }^{17}$ Reinhart and Rogoff, This Time is Different.

${ }^{18}$ Reinhart and Rogoff, This Time is Different. The crises that Reinhart and Rogoff study include both advanced and emerging economies: Argentina 2001, Chile 1980, Colombia 1998, Finland 1991, Indonesia 1997, Japan 1992, Korea 1997, Malaysia 1997, Mexico 1994, Norway 1987, Spain 1977, Sweden 1991, and Thailand 1997.

${ }^{19}$ Furceri, "Financial Crises and Public Debt."

${ }^{20}$ Furceri and Zdienicka, "The Consequences of Banking Crises."

${ }^{21}$ Abbas et al., "A Historical Public Debt Database.” Their database covers 174 countries in total. For most G-7 countries and some other advanced and emerging economies the data starts in 1880. Data for additional advanced and emerging economies are available from 1920 and for low-income countries data coverage starts in 1970.

${ }^{22}$ Reinhart and Rogoff, "Growth in a Time of Debt."

${ }^{23}$ Checherita and Rother, "The Impact of High and Growing Government Debt;” Kumar and Woo, "Public Debt and Growth."

${ }^{24}$ Schularick, "Staatsverschuldung in der westlichen Welt."

${ }^{25}$ Laeven and Valencia, "Systemic Banking Crises."

${ }^{26}$ Jorda, Schularick and Taylor, "Financial Crises."

${ }^{27}$ Ranciere et al., "Decomposing the Effects;" Demirgüc-Kunft and Detragiache, "Financial Liberalization;” Obstfeld, "The Global Capital Market.”

${ }^{28}$ Abbas et al., "A Historical Public Debt Database.”

${ }^{29}$ Tanzi and Schuknecht, Public Spending.

${ }^{30}$ See also Abbas et al., “A Historical Public Debt Database;” Schularick, "Staatsverschuldung in der westlichen Welt.”

${ }^{31}$ Ritschl, "Sustainability of High Public Debt."

${ }^{32}$ Ritschl, "Sustainability of High Public Debt."

${ }^{33}$ The figures are from the dataset compiled by Schularick and Taylor, "Credit Booms Gone Bust."

${ }^{34}$ Grossman, Unsettled Account.

${ }^{35}$ See Jorda, Schularick and Taylor, "When Credit Bites Back.”

${ }^{36}$ See also Reinhart and Rogoff, This Time is Different.

${ }^{37}$ I apply the same definition as above. A financial sector is large if the size of loans to GDP is above the sample average of $70 \%$ in the year of the crisis. 
${ }^{38}$ See Jorda, Schularick and Taylor, "When Credit Bites Back.” 


\section{References}

Abbas, S. Ali, Nazim Belhocine, Asmaa ElGanainy, and Mark Horton. “A Historical Public Debt Database.” IMF Working Paper, no. 10/245 (2010).

http://www.imf.org/external/pubs/ft/wp/2010/wp10245.pdf (accessed August 28, 2011).

Acharya, Viral V., Itamar Drechsler, and Philipp Schnabl. “A Pyrrhic Victory? Bank Bailouts and Sovereign Credit Risk.” National Bureau of Economic Research Working Paper, no. 17136 (2011). http://www.nber.org/papers/w17136 (accessed December 16, 2011).

Allessandri, Piergorgio, and Andrew G. Haldane. "Banking on the State.” Conference Paper, Federal Reserve Bank of Chicago 12th Annual International Banking Conference: The International Financial Crisis: Have the Rules of Finance Changed?, 2009. http://www.bankofengland.co.uk/publications/speeches/2009/speech409.pdf (accessed August 28, 2011).

Bernanke, Ben. "Financial Reform to Address Systemic Risk.” Speech at the Council on Foreign Relations, 2010.

http://www.federalreserve.gov/newsevents/speech/bernanke20090310a.htm (accessed September 2, 2011).

Bordo, Michael, Claudia Goldin, and Eugene White. The Defining Moment. The Great Depression and the American Economy in the Twentieth Century. Chicago: Chicago University Press, 1998.

Bordo, Michael, Barry Eichengreen, Daniela Klingebiel, and Maria Soledad Martinez-Peria. 2001. “Is the crisis problem growing more severe?” Economic Policy 16, no. 32 (2001): 51-82.

Cerra, Valeria, and Sweta C. Saxena. "Growth dynamics: The Myth of Economic Recovery." American Economic Review 98, no. 1 (2008): 439-457.

Checherita, Cristina, and Philipp Rother. “The Impact of High and Growing Government Debt on Economic Growth: An Empirical Investigation of the Euro Area.” ECB Working Paper, no.1237 (2010). http://www.ecb.int/pub/pdf/scpwps/ecbwp1237.pdf (accessed September 1, 2011).

Claessens, Stijn, Daniela Klingebiel, and Luc Laeven. 2004. "Resolving Systemic Financial Crises: Policies and Institutions.” World Bank Policy Research Working Paper, no. 3377 (2004). http://wwwwds.worldbank.org/external/default/WDSContentServer/IW3P/IB/2004/09/07/000160016 _20040907154538/additional/126526322_20041117165058.pdf (accessed August 24, 2011).

Clark, Tom, and Andrew Dilnot. “British fiscal policy since 1939.” In The Cambridge Economic History of Modern Britain. Volume III: Structural Change and Growth, 19392000, ed. Roderick Floud and Paul Johnson. 2004. Cambridge: Cambridge University Press, 2004.

Demirgüc-Kunt, Asli, and Enrica Detragiache. "Financial Liberalization and Financial Fragility.” IMF Working Paper, no. 98/83 (1998).

http:/www.imf.org/external/pubs/ft/wp/wp9883.pdf (accessed August 31, 2011).

Detragiache, Enrica, and Giang Ho. "Responding to Banking Crises: Lessons from CrossCountry Evidence.” IMF Working Paper, no. 10/18 (2010). http://www.imf.org/external/pubs/cat/longres.cfm?sk=23565.0 (accessed August 24, 2011).

Dewey, Davis R. The Financial History of the United States. New York: Kelley, 1968. 
Furceri, Davide. "Financial Crises and Public Debt: Empirical Evidence from OECD Countries” (OECD, Economic Department, 2010). http://www.um.es/dphacienda/eep2010/comunicaciones/eep2010-21.pdf (accessed August 24, 2011).

Furceri, Davide, and Aleksandra Zdienicka. “The Consequences of Banking Crises on Public Debt.” GATE Working Paper, no. 1015 (2010). http://hal.archivesouvertes.fr/docs/00/49/79/25/PDF/1015.pdf (accessed August 24, 2011).

Grossman, Richard S. Unsettled Account: The Evolution of Banking in the Industrialized World Since 1800. Princeton and Oxford: Princeton University Press, 2010.

Hamilton, Earl J. “Origin and Growth of the National Debt in Western Europe.” American Economic Review 37, no. 2 (1947): 118-130.

Horton, Mark, Manhoman Kumar and Paolo Mauro. "The State of Public Finances: A CrossCountry Fiscal Monitor.” IMF Staff Position Note, no. 09/12 (2009). http://www.imf.org/external/pubs/ft/spn/2009/spn0921.pdf (accessed August 24, 2011).

Jorda, Òscar, Moritz Schularick and Alan M. Taylor. "Financial Crises, Credit Booms, and External Imbalances: 140 Years of Lessons.” IMF Economic Review 59, no. 2 (2011): 340-378.

Jorda, Òscar, Moritz Schularick and Alan M. Taylor. "When Credit Bites Back: Leverage, Business Cycles, and Crises.” National Bureau of Economic Research Working Paper, no. 17621 (2011). http://www.nber.org/papers/w17621 (accessed December 16, 2011).

Kroszner, Randall S., Luc Laeven and Daniela Klingbiel. "Banking crises, financial dependence, and growth.” Journal of Financial Economics 84, no. 1 (2007): 187-228.

Kumar, Manmohan S., and Jaejoon Woo. "Public Debt and Growth.” IMF Working Paper, no. 10/174 (2010). http://www.imf.org/external/pubs/ft/wp/2010/wp10174.pdf (accessed December 16, 2011).

Laeven, Luc, and Fabian Valencia. “Systemic Banking Crises: A New Database.” IMF Working Paper, no. 08/224 (2008). http://www.imf.org/external/pubs/ft/wp/2008/wp08224.pdf (accessed September 1, 2011).

Nickel, Christiane, Philipp Rother and Lili Zimmermann. "Major Public Debt Reductions: Lessons from the Past, Lessons for the Future.” European Central Bank Working Paper, no. 1241 (2010). http://www.ecb.eu/pub/pdf/scpwps/ecbwp1241.pdf (accessed August 20, 2011).

Obstfeld, Maurice. “The Global Capital Market.” Journal of Economic Perspectives 12, no. 4 (1998): 9-30.

Ranciere, Romain, Aaron Tornell and Frank Westermann. "Decomposing the Effects of Financial Liberalization: Crisis vs. Growth.” Journal of Banking and Finance 30 (2006): 3331-3348.

Reinhart, Carmen M., and Vincent R. Reinhart. “After the Fall.” National Bureau of Economic Research Working Paper, no.16334 (2010). http://www.nber.org/papers/w16334 (accessed December 16, 2011).

Reinhart, Carmen M., and Kenneth S. Rogoff. “The Aftermath of Financial Crises.” National Bureau of Economic Research Working Paper, no. 14656 (2009). http://www.nber.org/papers/w14656 (accessed August 24, 2011).

Reinhart, Carmen M., and Kenneth S. Rogoff. "Growth in a Time of Debt.” American Economic Review 100, no. 2 (2010): 573-578. 
Reinhart, Carmen M., and Kenneth S. Rogoff. This Time is Different: Eight Centuries of Financial Folly. Princeton and Oxford: Princeton University Press, 2009.

Ritschl, Albrecht. "Sustainability of High Public Debt: What the Historical Record Shows." Swedish Economic Policy Review 3, no. 1 (1996): 175-198.

Schularick, Moritz. "Staatsverschuldung in der westlichen Welt (1880-2009).” Vierteljahrschrift fuer Sozial- und Wirtschaftsgeschichte 98, no. 3 (2011): 307-316.

Schularick, Moritz. “140 Years of Financial Crises: Old Dog, New Tricks.” Economic History Yearbook (Jahrbuch für Wirtschaftsgeschichte) (2011): 45-68.

Schularick, Moritz, and Alan M. Taylor. "Credit Booms Gone Bust: Monetary Policy, Leverage Cycles and Financial Crises, 1870-2008.” American Economic Review (forthcoming). [Working paper version: National Bureau of Economic Research Working Paper, no. 15512 (2009). http://www.nber.org/papers/w15512 (accessed December 16, 2011).]

Tanzi, Vito, and Ludgar Schuknecht. Public Spending in the 20th Century: A Global Perspective. Cambridge: Cambridge University Press, 2000.

Teulings, Coen N., and Nick Zubanov. "Is Economic Recovery a Myth? Robust Estimation of Impulse Responses.” Tinbergen Institute Discussion Paper, no. 040/3 (2010).

http://www.tinbergen.nl/discussionpapers/10040.pdf (accessed December 16, 2011). 


\section{Diskussionsbeiträge des Fachbereichs Wirtschaftswissenschaft der Freien Universität Berlin}

2012

2012/1 SCHULARICK, Moritz

Public Debt and Financial Crises in the Twentieth Century

Economics 